\title{
A new assessment of the Late Devonian antiarchan fish Bothriolepis leptocheira from South Timan (Russia) and the biotic crisis near the Frasnian-Famennian boundary
}

Ervīns Lukševičs, Pavel Beznosov, and Valdemārs Stūris

Acta Palaeontologica Polonica 62 (1), 2017: 97-119 doi:https://doi.org/10.4202/app.00265.2016

The species of the Late Devonian, earliest Famennian placoderm fish Bothriolepis jeremejevi has been downranked to subspecies Bothriolepis leptocheira jeremejevi comb. nov. in a result of detailed morphological studies of the type specimens and abundant new material from the type locality of the Sosnogorsk Formation, South Timan, Komi Republic, Russia. This taxon closely resembles Bothriolepis leptocheira leptocheira from Scotland, B. leptocheira curonica from Latvia, and B. leptocheira ssp. from Severnaya Zemlya differing only in small deviations of the size, proportions and shape of some plates of the armour. The composition of vertebrate assemblages from Scotland, Latvia, and Severnaya Zemlya containing $B$.

leptocheira demonstrates a reduced diversity of antiarch placoderm, acanthodian, and sarcopterygian fishes; however, the Sosnogorsk assemblage differs in a larger diversity containing very primitive tetrapod and diversified sarcopterygian fishes including dipnoans and porolepiforms but lacking acanthodians. Wide distribution of a single species of Bothriolepis and usually diminished diversity of vertebrates suggest that the earliest Famennian vertebrate assemblages conform the survival faunas of the latest Frasnian-earliest Famennian biotic crisis.

Key words: Placodermi, diversity, variability, Devonian, Frasnian, Famennian, Russia, South Timan.

Ervīns Lukševičs [ervins.luksevics@lu.lv] and Valdemārs Stūris [valdemars.sturis@gmail.com ], Department of Geology, Faculty of Geography and Earth Sciences, University of Latvia, Rainis Boulevard 19, Riga LV-1586, Latvia. Pavel Beznosov [beznosov@geo.komisc.ru], Institute of Geology, Komi Science Centre, Ural Branch of the Russian Academy of Sciences, 54, Pervomayskaya St., 167982 Syktyvkar, Russia. 
distribution, and reproduction in any medium, provided the original author and source are credited.

For Full text $(1,912.1 \mathrm{kB})$ 